\title{
PENGARUH PENERAPAN MODEL PEMBELAJARAN KOOPERATIF TIPE THINK TALK WRITE TERHADAP KOMUNIKASI MATEMATIKA SISWA
}

\author{
Abdul Asis ${ }^{1}$, Suaedi2 ${ }^{2}$, Muhammad Ilyas ${ }^{3}$ \\ Universitas Cokroaminoto Palopo ${ }^{123}$ \\ Email: abdulasis148@gmail.com¹, suadif@gmail.com², muhammadilyas949@gmail.com³
}

\begin{abstract}
Abstrak. Penelitian ini bertujuan untuk mengetahui pengaruh penerapan model pembelajaran kooperatif tipe Think, Talk, Write (TTW) untuk meningkatkan kemampuan komunikasi matematika siswa. penelitian ini merupakan penelitian quasi eksperimen dengan satuan eksperimen 1 kelas yaitu kelas VA SDN 1 Lalebbata. Satuan eksperimen ditentukan dengan menggunakan teknik purposive random sampling sebanyak 16 orang. Instrumen penelitian terdiri dari tes komunikasi matematika serta lembar observasi keterlaksanaan pembelajaran. Analisis data menggunakan analisis deskriptif dan inferensial serta kriteria pengaruh. Hasil penelitian ini adalah (1) kemampuan komunikasi matematika siswa sebelum penerapan model pembelajaran kooperatif tipe Thik Talk Write berada pada kategori cukup dengan rata-rata 65,38 (2) kemampuan komunikasi matematika siswa sesudah penerapan model pembelajaran kooperatif tipe Thik Talk Write berada pada kategori baik dengan rata-rata 79,81. (3) terdapat pengaruh penerapan model pembelajaran kooperatif tipe Thik Talk Write terhadap kemampuan komunikasi matematika dengan hasil uji hipotesis hasil uji hipotesis peningkatan kemampuan komunikasi matematika siswa diperoleh nilai sig. (2 tailed) $0,015<0,05$ menunjukkan bahwa hipotesis h1 diterima.
\end{abstract}

\section{Kata kunci: Model Pembelajaran Think Talk Write, Komunikasi Matematika}

\begin{abstract}
This study aims to determine the effect of applying think, talk, write (TTW) cooperative learning model to improve students' mathematical communication skills. This research is a quasi-experimental study with an experimental unit of 1 class, namely class VA at SDN 1 Lalebbata. Determination of the experimental unit using purposive sampling technique as many as 16 people. The research instrument consisted of a mathematical communication test and a learning implementation observation sheet. The data analysis technique used descriptive and inferential analysis as well as influence criteria. The results of this study are (1) students' mathematical communication skills before the application of the Thik Talk Write type cooperative learning model are in the sufficient category with an average of 65.38 (2) students' mathematical communication skills after the implementation of the Thik Talk Write type cooperative learning model are in the category good with an average of 79.81. (3) there is an effect of the application of the cooperative learning model type Thik Talk Write on mathematical communication skills with the results of hypothesis testing the results of hypothesis testing on increasing students' mathematical communication skills obtained sig. ( 2 tailed) $0.015<0.05$ indicates that the hypothesis $h 1$ is accepted.
\end{abstract}

Keywords: Think Talk Write Learning Model, Mathematical Communication.

\section{A. Pendahuluan}

Matematika merupakan ilmu pengetahuan yang penting dalam pembentukan keterampilan komunikasi, pemecahan masalah, kemampuan bekerjasama dan keterampilan berpikir agar mandiri dalam menghadapi tantangan kehidupan. Menurut The National Council of Teachers of Mathematics (NCTM) (2004) komunikasi sangat penting dalam proses belajar mengajar untuk tercapainya tujuan pembelajaran. Komunikasi yang dimaksud adalah komunikasi antara guru dengan siswa dan komunikasi antara siswa dengan siswa. Greenes \& Schulman (NTCM, 2004) mengemukakan bahwa komunikasi matematika merupakan kekuatan siswa dalam merumuskan konsep dan strategi matematika.

Penanaman konsep matematika memerlukan komunikasi yang baik, terutama dalam menafsirkan kalimat verbal menjadi kalimat matematika. Apabila terjadi kesalahan proses komunikasi dalam memberikan konsep, maka menimbulkan kesalahan pemahaman konsep. 
Siswa memperoleh informasi berupa konsep matematika yang diberikan guru atau bacaan merupakan proses transformasi informasi matematika dari sumber kepada siswa (Sudrajat, 2001). Sehingga siswa merespon informasi yang diberikan.berdasarkan pemahaman yang dimilikinya.

Menurut BSNP (2006), salah satu tujuan matematika adalah mengkomunikasikan gagasan dengan simbol, diagram, tabel, atau media lain untuk memperjelas keadaan atau masalah. Hal ini disebabkan matematika bersifat abstrak sehingga menuntut kemampuan guru agar memilih model pembelajaran yang digunakan sesuai dengan kemampuan siswa untuk mencapai tujuan pembelajaran. Salah satu upaya yang dilakukan guru adalah dengan menggunakan model pembelajaran kooperatif. Menurut Arends (2008), salah satu ciri model pembelajaran kooperatif adalah siswa bekerja dalam kelompok bekerjasama untuk menyelesaikan materi belajar.

Salah satu model pembelajaran kooperatif adalah tipe Think-Talk-Write (TTW). Model pembelajaran TTW yang dikenalkan oleh Huinker \& Laughl. Model pembelajaran TTW dibangun melalui proses berpikir, berbicara, dan menulis. Sehingga dengan menggunakan model pembelajaran kooperatif tipe TTW diharapkan mendorong siswa untuk berpikir kritis, dan meningkatkan hasil belajar. Model pembelajaran TTW mengembangkan ketrampilan berpikir kritis dan kreatif siswa melalui soal open ended (Soimin, 2016). Selain itu siswa dapat berinteraksi dan berdiskusi dengan kelompok, sehingga melibatkan siswa secara aktif dalam belajar.

Langkah-langkah pembelajaran kooperatif tipe TTW menurut Maftuh dan Nurmani (Hamdayana, 2014) adalah penyajian materi oleh guru, pengelompokkan siswa yang terdiri dari 3-4 orang siswa. Setelah siswa berada dalam kelompok-kelompok, guru membagikan LKPD kepada tiap siswa, dan tiap siswa membaca LKPD dan membuat catatan kecil atas jawabannya secara individu. Hasil jawaban siswa didiskusikan dengan angota kelompoknya. Kemudian siswa merumuskan pengetahuan yang diperoleh dari hasil diskusi dan dituangkan dalam bentuk tulisan dengan menggunakan bahasanya sendiri, tiap kelompok mempresentasikan hasil diskusinya, guru meminta kelompok lain untuk menanggapi jawaban kelompok yang sedang presentasi.

Berdasarkan beberapa pendapat di atas, dapat diyakini bahwa model pembelajaran TTW membiasakan siswa berpikir dan berkomunikasi dengan teman, guru, dan bahkan dengan diri mereka sendiri. Dengan berkomunikasi yang tepat, siswa akan memperoleh hasil belajar yang maksimal. Jadi dapat disimpulkan bahwa model pembelajaran TTW melatih siswa membangun pemikiran dalam memahami konsep. Model pembelajaran TTW membiasakan siswa berdiskusi dengan temannya tentang pemikirannya dan menulis hasil pemikiranya tersebut dalam proses belajar.

Komunikasi adalah sebuah cara berbagi pikiran atau ide. Melalui komunikasi ide-ide direfleksikan, diperbaiki, didiskusikan, dan diubah. Guru berperan sebagai komunikator, siswa sebagai komunikan, dan materi yang dikomunikasikan berisi pesan berupa ilmu pengetahuan (Yuniarti, 2016). Dalam pembelajaran, komunikasi bisa terjadi dengan banyak arah dan perubahan peran, yaitu antara guru dengan siswa dan sebaliknya, serta antara siswa dengan siswa (Suherman, 2003). Komunikasi merupakan bagian penting dari pembelajaran matematika. Dengan adanya komunikasi, sebuah ide menjadi objek refleksi, perbaikan, diskusi dan perubahan, sehingga dapat membantu membangun makna dan menetapkan ide-ide serta memperjelas pemahaman pada belajar matematika.

Menurut Isoda (Yuniarti, 2016), guru membantu siswanya untuk belajar bagaimana merefleksinya, karakterisasi, dan mendiskusikan masalah. Jawaban siswa bukanlah yang utama, namun cara siswa berinisiatif sendiri, membentuk atau menemukan jawaban yang valid. Jadi, kemampuan komunikasi matematika dipengaruhi oleh bagaimana peran guru dalam pembelajaran. Guru harus memberikan peluang-peluang kepada siswa untuk mengembangkan 
kemampuan matematikanya. Karena karakteristik matematika penuh dengan istilah dan simbol, sehingga ada siswa yang mampu menyelesaikan soal matematika dengan baik, tetapi tidak mengerti apa yang sedang dikerjakannya.

Selanjutnya Isoda (Yuniarti, 2016) menyatakan komponen komunikasi matematika, yaitu penggunaan bahasa yang tepat untuk menyampaikan pemahaman konseptual, menekankan penalaran logis, membedakan penjelasan konseptual dan deskripsi prosedural, membuat representasi yang bermakna dan menumbuhkan simpati. Menurut Kadir (Hodiyanto, 2017), kemampuan komunikasi matematika diukur dengan memberikan skor siswa dalam menjawab soal dengan menggambar, membuat ekspresi matematik dan menuliskan jawaban dengan bahasa sendiri. Lebih lanjut menurut Ansari (2012), pengukuran kemampuan komunikasi matematika siswa dalam pembelajaran matematika dapat dilakukan dengan pemberian soal uraian yang bisa mengungkapkan kemampuan komunikasi matematika.

Berdasarkan uraian di atas, kemampuan komunikasi matematika terdiri dari komunikasi lisan dan komunikasi tulisan. Komunikasi lisan meliputi kemampuan menjelaskan ide atau konsep secara lisan pada saat diskusi, sedangkan komunikasi tulisan meliputi kemampuan menyatakan masalah dalam model matematika. Jadi, komunikasi matematika merupakan kemampuan siswa dalam menyatakan suatu konsep atau ide matematika dalam pembelajaran secara lisan dan tulisan.

Indikator kemampuan komunikasi matematika yang digunakan dalam penelitian ini adalah:

a. Menulis (written text), yaitu menjelaskan ide atau penyelesaian masalah atau gambar dengan menggunakan bahasa sendiri.

b. Menggambar (drawing), yaitu menjelaskan ide atau penyelesaian masalah dalam bentuk gambar.

c. Ekspresi matematika (matematical ekpression), yaitu menyatakan masalah atau peristiwa sehari-hari dalam kalimat matematika

Berdasarkan latar belakang di atas dapat dirumuskan masalah bagaimanakah pengaruh model pembelajaran kooperatif tipe Think Talk Write (TTW) terhadap kemampuan komunikasi matematika siswa kelas V di SDN 1 Lalebbata Palopo.

\section{B. Metode Penelitian}

Penelitian ini merupakan penelitian dengan pendekatan kuantitatif. Jenis penelitian yang digunakan adalah penelitian eksperimen yaitu suatu bentuk penelitian yang di dalamnya ditemukan minimal satu variabel yang dimanipulasi untuk mempelajari hubungan sebab akibat (Ilyas, 2015). Penelitian eksperimen yang akan dilakukan adalah penelitian eksperimen semu yaitu meneliti tentang kemampuan pemecahan masalah dan kemampuan komunikasi matematika siswa sebelum dan setelah diajar dengan menggunakan model pembelajaran kooperatif tipe TTW.

Desain penelitian yang digunakan adalah One Group Pretest-Posttest Design yaitu penelitian yang menggunakan satu kelompok perlakuan dengan pemberian pretest dan posttest (Sugiyono, 2018). Desian penelitian One Group Pretest-Posttest Design adalah sebagai berikut:

$$
\mathrm{O}_{1} \longrightarrow \mathrm{X} \longrightarrow \mathrm{O}_{2}
$$

Gambar 1. Desain Penelitian One Group Pretest-Posttest Design

Keterangan:

$O_{1}$ : Tes awal (Pretest) sebelum diberikan perlakuan

$\mathrm{O}_{2}$ : Tes akhir (Posttest) setelah diberikan perlakuan 
$\mathrm{X}$ : Perlakuan terhadap kelas eksperimen yaitu dengan menerapkan model pembelajaran kooperatif tipe Think, Talk, Write (TTW)

Penelitian ini dilakukan di SDN 1 Lalebbata yang beralamat di Jalan Andi Jemma No 4, Amassangan, kecamatan Wara Kota Palopo. Satuan eksperimen adalah seluruh siswa kelas V SDN 1 Lalebbata Palopo pada semester genap tahun pelajaran 2020/2021. Penentuan satuan perlakuan dalam penelitian ini menggunakan teknik purposive random sampling. Purposive sampling adalah pengambilan sampel yang tidak dilakukan secara acak, tapi ditentukan sendiri oleh peneliti dengan beberapa pertimbangan yaitu peserta didik bersedia menjadi responden dan mendapatkan izin orang tua. Satuan perlakuan pada penelitian ini sebanyak 16 orang siswa kelas VA SDN 1 Lalebbata Palopo. Instrumen penelitian terdiri dari tes komunikasi matematika dan lembar observasi keterlaksanaan pembelajaran. teknik pengumpulan data menggunakan tesdan lembar observasi. Berikut pedoman penskoran tes kemampuan komunikasi matematika.

Tabel 1. Pedoman Penskoran Tes Peningkatan Kemampuan Komunikasi Matematika

\begin{tabular}{|c|c|c|}
\hline $\begin{array}{l}\text { Indikator Kemampuan } \\
\text { Komunikasi Matematika }\end{array}$ & Kriteria & Skor \\
\hline \multirow{4}{*}{$\begin{array}{l}\text { Memberikan jawaban } \\
\text { soal dengan menggambar } \\
(\text { drawing) }\end{array}$} & Tidak ada jawaban & 0 \\
\hline & Memberi jawaban soal yang tidak relevan dengan gambar & 1 \\
\hline & $\begin{array}{l}\text { Memberi jawaban soal yang relevan dengan gambar namun masih } \\
\text { terdapat kesalahan dan kurang lengkap }\end{array}$ & 2 \\
\hline & Memberi jawaban soal denga benar dan relevan dengan gambar & 3 \\
\hline \multirow{4}{*}{$\begin{array}{l}\text { Membuat ekspresi } \\
\text { matematik (mathematical } \\
\text { expression) }\end{array}$} & Tidak Ada Jawaban & 0 \\
\hline & $\begin{array}{l}\text { Tidak dapat menyusun model matematika dalam bentuk ekspresi } \\
\text { matematika dengan benar }\end{array}$ & 1 \\
\hline & $\begin{array}{l}\text { Menyusun model matematika dalam bentuk ekspresi matematika } \\
\text { namun masih terdapat kesalahan dan kurang lengkap }\end{array}$ & 2 \\
\hline & $\begin{array}{l}\text { Menyusun model matematika dalam bentuk gambar atau ekspresi } \\
\text { matematika dengan benar }\end{array}$ & 3 \\
\hline \multirow{4}{*}{$\begin{array}{l}\text { Menuliskan jawaban } \\
\text { dengan bahasa sendiri } \\
\text { (written texts) }\end{array}$} & Tidak Ada Jawaban & 0 \\
\hline & Tidak dapat menuliskan jawaban menggunakan bahasanya sendiri & 1 \\
\hline & $\begin{array}{l}\text { Menuliskan jawaban menggunakan bahasanya sendiri, namun } \\
\text { masih terdapat kesalahan dan kurang lengkap }\end{array}$ & 2 \\
\hline & $\begin{array}{l}\text { Menuliskan jawaban menggunakan bahasanya sendiri dengan } \\
\text { benar }\end{array}$ & 3 \\
\hline
\end{tabular}

Sumber data: dokumen pribadi peneliti, 2020

Analisis data pada penelitian ini menggunakan analisis data deskriptif dan inferensial. Analisis data deskriptif tentang kemampuan komunikasi matematika dan keterlaksanaan model pembelajaran kooperatif tipe TTW. Analisis data inferensial tentang pengaruh model pembelajaran kooperatif tipe TTW untuk meningkatkan kemampuan komunikasi matematika. Kriteria pengaruh ditetapkan sebagai berikut:

\section{a. Secara deskriptif}

Kemampuan pemecahan masalah matematika dan kemampuan komunikasi matematika siswa dikatakan berpengaruh apabila secara deskriptif memenuhi kriteria sebagai berikut:

1. Rata-rata gain ternomalisasi minimal berada pada kategori sedang $(0,3 \leq \mathrm{g}<0,7)$.

2. Rata-rata hasil observasi keterlaksanaan model pembelajaran kooperatif tipe TTW minimal berada pada kategori baik (80 - 89).

\section{b. Secara inferensial}

Peningkatan kemampuan pemecahan masalah dan komunikasi matematika siswa dengan model pembelajaran kooperatif tipe TTW lebih dari skor rata-rata gain ternomalisasi.

\section{Hasil Penelitian dan Pembahasan}

Penelitian ini diawali dengan pretest pada hari selasa 2 Maret 2021 jam 07.30-08.10 yang diikuti oleh 16 siswa. Pada saat pretest tampak siswa merasa kesulitan dalam mengerjakan soal. Hal ini disebabkan oleh jenis soal yang merupakan soal open ended yang bertujuan untuk 
mengetahui dan melatih kemampuan berpikir, menjawab pertanyaan dengan menuliskan jawaban menggunakan kata-katanya sendiri. Namun karena siswa belum terbiasa dengan soal open ended, peneliti memberikan arahan cara menjawab soal pretest.

Pertemuan pertama dilaksanakan pada hari rabu 3 Maret 2021 disampaikan materi tentang penyajian data. Pada pertemuan ini, peneliti terlalu lama meyampaikan kegiatan pendahuluan lebih dari yang direncanakan selama 5 menit. Hal ini disebabkan oleh karena peneliti terlalu lama memberikan motivasi kepada siswa tentang pentingnya mempelajari materi penyajian data dalam kehidupan sehari-hari. Akibatnya pada pertemuan ini, peneliti tidak menjelaskan materi yang dipelajari, langsung meminta siswa untuk mengamati materi yang ada pada LKPD.

Pada kegiatan ini, siswa secara berkelompok mengumpulkan ukuran data ukuran sepatu dan menuliskan di bukunya masing-masing. Kemudian menentukan ukuran yang paling besar dan ukuran yang paling kecil. Setelah itu data diurutkan dari yang terkecil ke yang terbesar. Dari hasil kegiatan kelompoknya, siswa diminta untuk mempresentasikan hasil diskusinya dan menuliskan kesimpulan berdasarkan bahasanya sendiri. Pada kegiatan penutup, peneliti tidak sempat memberikan penguatan dan menyampaikan materi yang akan dipelajari pada pertemuan selanjutnya. Hal ini disebabkan karena keterbatasan waktu.

Pertemuan kedua dilaksanakan pada hari Selasa, 9 Maret 2021 mempelajari materi tentang cara penyajian data. Pada pertemuan ini kegiatan pembelajaran berjalan sesuai yang direncanakan. Siswa mulai terbiasa dengan kegiatan berpikir (think), berdiskusi dengan temannya dan mempresentasikan hasil diskusinya (talk), serta membuat kesimpulan dengan menggunakan bahasanya sendiri pada buku tulisnya (write) Pada pertemuan ini, siswa juga mulai terbiasa dengan soal open ended yang diberikan pada LKPD.

Pertemuan ketiga dilaksanakan pada hari Rabu, 10 Maret 2021 mempelajari materi membaca data. Pada pertemuan ini peneliti cara membaca data yang disajikan dalam bentuk tabel, diagram dan piktogram. Kemampuan yang berkembang pada pertemuan ini adalah kemampuan berpikir (think), kemampuan berbicara (talk) dan menulis (write). Sehingga dapat meningkatkan kemampuan komunikasi matematika pada indikator menuliskan jawaban dengan menggunakan bahasa sendiri. Hal ini tampak pada jawaban siswa yang ada di LKPD, ketika disajikan data dalam bentuk diagram, siswa dapat memberikan informasi tentang situasi yang digambarkan pada diagram.

Pertemuan keempat dilaksanakan pada hari Selasa, 16 Maret 2021 mempelajari cara menginterpretasikan data. Kemampuan yang dikembangkan pada pertemuan ini adalah kemampuan berpikir (think), dimana siswa dituntut untuk menganalisis data yang diberikan. Pada pertemuan ini siswa diberikan tabel banyaknya permen yang terjual setiap hari selama 1 minggu, kemudian siswa diminta menuliskan informasi yang ada pada tabel.

Dalam hal ini siswa mampu meningkatkan kemampuan pemecahan masalah pada indikator memahami masalah, merencanakan penyelesaian, melaksanakan penyelesaian yang dipilih serta memeriksa kembali kebenaran jawaban. Melalui LKPD yang diberikan, siswa mampu menentukan data tertinggi dan data terendah serta rata-rata penjualan per hari. Selain meningkatkan kemampuan pemecahan masalah, pada pertemuan ini siswa mampu meningkatkan kemampuan komunikasi matematika pada indikator membuat ekspresi matematika dan menuliskan jawaban dengan bahasanya sendiri.

Pertemuan kelima dilaksanakan pada hari Rabu, 17 Maret 2021 dengan materi menyelesaikan masalah tentang penyajian data tunggal. Kegiatan pada pertemuan ini meningkatkan kemampuan pemecahan masalah dan komunikasi matematika. Hal ini dapat dilihat dari jawaban siswa pada LKPD. Siswa mampu memahami masalah, merencanakan penyelesaian, melaksanakan penyelesaian yang dipilih serta memeriksa kembali kebenaran jawaban. Selain itu siswa mampu memberikan jawaban soal dalam bentuk gambar diagram, 
membuat ekspresi matematika dalam menentukan rata-rata data serta mampu menuliskan jawaban dengan menggunakan bahasa sendiri.

Penelitian diakhiri dengan pelaksanaan postest pada hari Selasa, 23 Maret 2021. Pada saat mengerjakan postest tampak siswa lancar mengerjakan tes. Hal ini menunjukkan bahwa ada indikasi pengaruh penggunaan model pembelajaran kooperatif tipe TTW untuk meningkatkan kemampuan siswa dalam memecahkan masalah dan komunikasi matematika.

Data kemampuan komunikasi matematika siswa diperoleh dari hasil pretest kemampuan komunikasi matematika pada materi penyajian data. Hasil pretest kemampuan komunikasi matematika diperiksa berdasarkan pedoman penskoran berupa rubrik penilaian dengan kriteria yang telah ditetapkan pada tabel 1. Analisis data statistik deskriptif terhadap skor kemampuan komunikasi matematika siswa sebelum belajar menggunakan model pembelajaran kooperatif tipe TTW disajikan pada tabel berikut:

Tabel 2. Statistik deskriptif skor pretest kemampuan komunikasi matematika

\begin{tabular}{ll}
\hline Statistik & Nilai Statistik Pretest \\
\hline Ukuran Sampel & 16 \\
Nilai Ideal & 100 \\
Nilai Tertinggi & 88 \\
Nilai Terendah & 42 \\
Rentang Nilai & 46 \\
Nilai Rata-rata & 65,38 \\
Variansi & 206,25 \\
Standar Deviasi & 14,36 \\
\hline
\end{tabular}

Sumber: Hasil analisis data primer 2021

Berdasarkan tabel 2 di atas, nilai rata-rata pretest kemampuan komunikasi matematika siswa kelas VA SDN 1 Lalebbata adalah 65,38 dengan standar deviasi 14,36 berada pada kriteria cukup. Dari nilai yang diperoleh siswa pada saat pretest kemampuan komunikasi matematika sebelum belajar menggunakan model pembelajaran kooperatif tipe think talk write (TTW) dikelompokkan berdasarkan kriteria yang telah ditetapkan disajikan pada tabel berikut:

Tabel 3. Distribusi frekuensi hasil pretest kemampuan komunikasi matematika

\begin{tabular}{llll}
\hline \multirow{2}{*}{ Nilai } & \multirow{2}{*}{ Kriteria } & Pretest & \\
\cline { 3 - 4 } & & Frekuensi & Persentase \\
\hline $85,00-100$ & Sangat Baik & 1 & $6,25 \%$ \\
$70,00-84,99$ & Baik & 4 & $25,00 \%$ \\
$55,00-69,99$ & Cukup & 7 & $43,75 \%$ \\
$40,00-54,99$ & Rendah & 4 & $25,00 \%$ \\
$0,00-39,99$ & Sangat Rendah & 0 & $0,00 \%$ \\
\hline
\end{tabular}

Sumber: Hasil analisis data primer 2021

Berdasarkan tabel di atas, dari 16 siswa yang mengikuti pretest, terdapat 1 orang atau $6,25 \%$ siswa memiliki kemampuan komunikasi matematika sangat baik, 4 orang atau 25\% siswa memiliki kemampuan komunikasi matematika siswa baik, 7 orang atau 43,75\% siswa memiliki kemampuan komunikasi matematika cukup, dan 4 orang atau $25 \%$ siswa memiliki kemampuan komunikasi matematika rendah.

Hal ini disebabkan oleh sebagian besar siswa merasa kesulitan memahami soal tes yang diberikan karena jenis soal open ended. Siswa belum terbiasa menggunakan kemampuan menjawab soal dengan gambar, membuat ekspresi matematika dan menuliskan jawaban dengan bahasa sendiri. Selain itu, materi penyajian data merupakan materi baru yang belum pernah diajarkan sebelumnya di SD. Hal ini menyebabkan kemampuan awal komunikasi matematika siswa berada pada kategori cukup. 
Data kemampuan komunikasi matematika siswa diperoleh dari hasil postest kemampuan komunikasi matematika siswa pada materi penyajian data. Hasil postest kemampuan komunikasi matematika diperiksa berdasarkan pedoman penskoran berupa rubrik penilaian dengan kriteria yang telah ditetapkan pada tabel 1. Analisis data statistik deskriptif terhadap skor kemampuan komunikasi matematika siswa sebelum belajar menggunakan model pembelajaran kooperatif tipe think talk write (TTW) disajikan pada tabel berikut:

Tabel 4. Statistik deskriptif skor postest kemampuan komunikasi matematika

\begin{tabular}{ll}
\hline Statistik & Nilai Statistik Postest \\
\hline Ukuran Sampel & 16 \\
Nilai Ideal & 100 \\
Nilai Tertinggi & 100 \\
Nilai Terendah & 58 \\
Rentang Nilai & 42 \\
Nilai Rata-rata & 79,81 \\
Variansi & 147,50 \\
Standar Deviasi & 12,14 \\
\hline
\end{tabular}

Sumber: Hasil analisis data primer 2021

Berdasarkan tabel di atas, nilai rata-rata postest kemampuan komunikasi matematika matematika siswa kelas VA SDN 1 Lalebbata adalah 79,81 dengan standar deviasi 12,14 berada pada kriteria baik. Dari nilai yang diperoleh siswa pada saat postest kemampuan komunikasi matematika sebelum belajar menggunakan model pembelajaran kooperatif tipe think talk write (TTW) dikelompokkan berdasarkan kriteria yang telah ditetapkan pada tabel 5 disajikan pada tabel berikut:

Tabel 5 Distribusi frekuensi hasil postest kemampuan komunikasi matematika

\begin{tabular}{llll}
\hline \multirow{2}{*}{ Nilai } & \multirow{2}{*}{ Kriteria } & Postest & \\
\cline { 3 - 4 } & & Frekuensi & Persentase \\
\hline $85,00-100$ & Sangat Baik & 6 & $37,5 \%$ \\
$70,00-84,99$ & Baik & 7 & $43,75 \%$ \\
$55,00-69,99$ & Cukup & 3 & $18,75 \%$ \\
$40,00-54,99$ & Rendah & 0 & $0,00 \%$ \\
$0,00-39,99$ & Sangat Rendah & 0 & $0,00 \%$ \\
\hline
\end{tabular}

Sumber: Hasil analisis data primer 2021

Berdasarkan tabel di atas, dari 16 siswa yang mengikuti postest, terdapat 6 orang atau $37,5 \%$ siswa memiliki kemampuan komunikasi matematika sangat baik, 7 orang atau $43,75 \%$ siswa memiliki kemampuan komunikasi matematika baik, dan 3 orang atau 18,75\% siswa memiliki kemampuan komunikasi matematika cukup. Secara deskriptif, dapat dikatakan bahwa kemampuan komunikasi matematika siswa kelas VA SDN 1 Lalebbata menjadi lebih baik setelah belajar menggunakan model pembelajaran kooperatif tipe think talk write (TTW).

Setelah belajar menggunakan model pembelajaran kooperatif tipe think, talk, write (TTW), kemampuan komunikasi matematika siswa mengalami peningkatan. Hal ini disebabkan oleh kebiasaan siswa menggunakan kemampuan menjawab soal dengan gambar, membuat ekspresi matematika dan menuliskan jawaban dengan menggunakan bahasanya sendiri pada saat penerapan model pembelajaran kooperatif tipe think, talk, write (TTW) melalui LKPD yang diberikan pada siswa. Sehingga secara deskriptif, dapat dikatakan bahwa kemampuan komunikasi matematika siswa kelas VA SDN 1 Lalebbata menjadi lebih baik setelah belajar menggunakan model pembelajaran kooperatif tipe think talk write (TTW). 
Untuk mengetahui peningkatan kemampuan komunikasi matematika siswa, dilakukan analisis nilai gain berdasarkan hasil pretest dan postest. Hasil analisis nilai gain untuk mengetahui peningkatan kemampuan komunikasi matematika siswa sebelum dan sesudah belajar menggunakan model pembelajaran kooperatif tipe think talk write (TTW) disajikan pada tabel berikut:

Tabel 6 Statistik deskriptif peningkatan kemampuan komunikasi matematika

\begin{tabular}{ll}
\hline Statistik & Nilai Statistik Gain \\
\hline Ukuran Sampel & 16 \\
Nilai Ideal & 1,00 \\
Nilai Tertinggi & 1,00 \\
Nilai Terendah & 0,20 \\
Rentang Nilai & 0,80 \\
Nilai Rata-rata & 0,44 \\
Variansi & 0,05 \\
Standar Deviasi & 0,23 \\
\hline
\end{tabular}

Sumber: Hasil analisis data primer 2021

Berdasarkan tabel di atas, nilai gain rata-rata peningkatan kemampuan komunikasi matematika siswa kelas VA SDN 1 Lalebbata adalah 0,44 dengan standar deviasi 0,23 berada pada kriteria sedang. Dari nilai gain yang diperoleh siswa sebelum dan sesudah belajar menggunakan model pembelajaran kooperatif tipe think talk write (TTW) dikelompokkan berdasarkan kriteria gain ternormalisasi yang telah ditetapkan pada tabel 4 disajikan pada tabel berikut:

Tabel 7. Klasifikasi gain ternormalisasi kemampuan komunikasi matematika siswa

\begin{tabular}{llll}
\hline Koefisien Normalisasi Gain & Klasifikasi & Frekuensi & Persentase \\
\hline $\mathrm{g}<0,3$ & Rendah & 3 & $18,75 \%$ \\
$0,3 \leq \mathrm{g}<0,7$ & Sedang & 11 & $68,75 \%$ \\
$\mathrm{~g} \geq 0,7$ & Tinggi & 2 & $12,50 \%$ \\
\hline Jumlah & & 16 & $100 \%$ \\
\hline
\end{tabular}

Sumber: Hasil analisis data primer 2021

Berdasarkan tabel di atas, dari 16 siswa yang mengikuti pembelajaran, terdapat 3 orang atau $18,75 \%$ siswa mengalami peningkatan kemampuan komunikasi matematika dengan klasifikasi rendah, 11 orang atau $68,75 \%$ siswa mengalami peningkatan kemampuan komunikasi matematika dengan klasifikasi sedang dan 2 orang atau 12,5\% siswa mengalami peningkatan kemampuan komunikasi matematika dengan klasifikasi tinggi. Secara deskriptif, dapat dikatakan bahwa kemampuan komunikasi matematika siswa kelas VA SDN 1 Lalebbata meningkat dan memperoleh pengetahuan setelah belajar menggunakan model pembelajaran kooperatif tipe think talk write (TTW).

Berdasarkan hasil penelitian, capaian rata-rata hasil observasi keterlaksanaan pembelajaran dengan model pembelajaran kooperatif tipe think talk write (TTW) adalah 85,56 berada pada kategori baik. Pada pelaksanaan pembelajaran, dimulai dengan menyampaikan tujuan pembelajaran dan memotivasi siswa, menyajikan informasi melalui pengamatan terhadap bahan ajar dan memberi kesempatan peserta didik berpikir (think) dan bertanya tentang materi yang akan dipelajari. Hal ini sesuai dengan pendapat Suyatno (2009) bahwa model pembelajaran TTW dimulai dengan berpikir melalui bahan bacaan.

Selanjutnya guru mengorganisasikan peserta didik ke dalam kelompok belajar dan membimbing kelompok bekerja dan belajar mendiskusikan permasalahan yang ada di LKPD. Hal ini sejalan dengan pendapat Komalasari (2010) bahwasanya model pembelajaran 
cooperative adalah pembelajaran dimana siswa belajar dalam kelompok secara kolaboratif dengan struktur kelompoknya yang bersifat heterogen.

Guru mengevaluasi hasil diskusi peserta didik yang dipresentasikan (talk) di depan kelas dan memberikan penghargaan atas kerja kelompok. Guru memberikan kesempatan kepada siswa untuk menuliskan hasil pekerjaannya sebagai bahan kesimpulan (write) serta memberikan penguatan dan menyampaikan materi yang akan dipelajari pada pertemuan berikutnya. Hal ini sesuai dengan pendapat Huinker dan Laughlin (Huda, 2013) bahwa model pembelajaran think talk write (TTW) melibatkan siswa dalam berpikir setelah proses membaca, berbicara atau diskusi dengan temannya, kemudian menuliskan hasil kesimpulannya.

Temuan-temuan dalam penerapan model pembelajaran kooperatif tipe think talk write (TTW) diantaranya adalah pada pertemuan 1, siswa diberikan kegiatan untuk merangsang proses berpikir, bicara dan menulis serta memecahkan masalah tentang penyajian data melalui kegiatan pembuatan laporan hasil pengumpulan data yang berkaitan dengan diri siswa. Dalam hal ini siswa diminta mengumpulkan data ukuran sepatu melalui wawancara terehadap teman sekelompoknya. Kemudian menulis data yang diperoleh dalam buku catatannya, menentukan data paling tinggi dan rendah serta mengurutkan data dari terendah ke tertinggi. Soal ini merupakan soal open ended yang membuat siswa membutuhkan waktu yang agak lama untuk memahami soal dan menuliskan data hasil pengamatannya

Pada pertemuan 2, siswa diberikan materi tentang cara menyajikan data dalam berbagai bentuk seperti tabel, diagram atau grafik. Hal ini dilakukan untuk mengembangkan kemampuan komunikasi matematika siswa yaitu siswa dapat membuat gambar, dan menuliskan jawaban dengan bahasanya sendiri. Pada pertemuan ini pembelajaran dapat terlaksana dengan baik dan siswa sudah mulai terbiasa dengan model pembelajaran yang diterapkan.

Pertemuan 3 pada penelitian ini tentang cara membaca data berdasarkan tabel atau diagram yang diberikan. Hal ini bertujuan untuk mengembangkan kemampuan memahami masalah dan kemampuan menuliskan jawaban dengan bahasa sendiri. Pada pertemuan ini kegiatan dapat terlaksana dengan baik dan siswa mampu menuliskan informasi yang ada di dalam diagram yang diberikan, walaupun hanya membuat deskripsi tentang banyaknya pengunjung perpustakaan tiap hari dan menentukan data tertinggi dan terendah. Untuk lebih menguatkan kemampuan siswa memahami masalah, guru menambahkan informasi tentang cara membandingkan data per hari meningkat atau menurun. Kegiatan yang dilakukan guru dikuatkan dengan pendapat Isoda (Yuniarti, 2016), guru menolong siswanya bagaimana mereka berinisiatif sendiri, membentuk atau menemukan jawaban yang valid.

Pada pertemuan 4 tentan materi menginterpretasikan data, siswa diminta menganalisis data sesuai dengan kemampuannya. Harapan pada kegiatan ini, siswa dapat memahami masalah, menentukan rencana penyelesaian dan meningkatkan kemampuan komunikasi matematika untuk membuat ekspresi matematika, menulis jawaban dengan bahasanya sendiri serta menyajikan gambar grafik atau diagram dari data dalam bentuk tabel. Pada kegiatan ini ternyata kemampuan siswa yang muncul adalah mampu memahami masalah, merencanakan penyelesaian, membuat ekspresi matematika dan menulis jawaban dengan bahasa sendiri. Untuk kemampuan menyajikan gambar diagram atau grafik berdasarkan tabel yang diketahui belum nampak. Sehingga guru memberikan informasi kepada siswa bahwa tabel yang ada di dalam soal dapat disajikan dalam bentuk diagram. Hal ini merupakan bentuk komunikasi guru dalam memberikan pengetahuan sebagaimana pendapat Yuniarti (2016) bahwa guru berperan sebagai komunikator, siswa sebagai komunikan, dan materi yang dikomunikasikan berisi pesan berupa ilmu pengetahuan.

Pertemuan 5 merupakan pertemuan terakhir yaitu tentang kemampuan menyelesaikan masalah sehari-hari yang berkaitan dengan penyajian data. Kegiatan ini dapat terlaksana dengan baik karena siswa sudah terbiasa pada pertemuan-pertemuan sebelumnya tentang cara 
mengerjakan soal open ended yang membiasakan siswa berpikir serta menyelesaikan masalah berdasarkan pengalaman yang dimiliki.

Berdasarkan hasil penelitian bahwa kemampuan komunikasi matematika awal berada pada kategori cukup. Dilihat dari indikator kemampuan komunikasi matematika siswa, kemampuan awal siswa pada indikator membuat ekspresi matematika lebih rendah daripada kemampuan menuliskan jawaban dengan bahasa sendiri dan kemampuan memberikan jawaban soal dengan gambar. Untuk itu, peneliti menerapkan model pembelajaran kooperatif tipe TTW sebagai upaya meningkatkan kemampuan siswa dalam komunikasi matematika. Hal ini dikuatkan oleh Husna (2016) dalam penelitiannya menunjukkan bahwa kemampuan komunikasi matematika siswa secara keseluruhan yang diajarkan dengan strategi pembelajaran TTW lebih tinggi dari pada siswa diajarkan dengan pembelajaran konvensional.

Setelah di diterapkan model pembelajaran kooperatif tipe TTW, kemampuan komunikasi matematika siswa meningkat berada pada kategori baik. Kemampuan komunikasi matematika tiap indikator juga merata. Hal ini menunjukkan bahwa model pembelajaran kooperatif tipe TTW berpengaruh terhadap kemampuan komunikasi matematika siswa. Yaitu mampu meningkatkan kemampuan menjawab soal dengan gambar, membuat ekspresi matematika dan menuliskan jawaban dengan bahasanya sendiri. Karena dalam model pembelajaran kooperatif tipe TTW, siswa dibiasakan untuk menulis hasil diskusi dari hasil pemikirannya dalam memecahkan masalah dengan menggunakan bahasa sendiri. Sehingga siswa memiliki pengalaman yang dapat meningkatkan kemampuan komunikasi matematikanya.

\section{Kesimpulan dan Saran}

1. Kemampuan komunikasi matematika siswa sebelum penerapan model pembelajaran kooperatif tipe Thik Talk Write berada pada kriteria cukup dengan rata-rata 65,38. Hal ini disebabkan siswa belum terbiasa menggunakan kemampuan komunikasi matematika dalam menjawab soal.

2. Kemampuan komunikasi matematika siswa sesudah penerapan model pembelajaran kooperatif tipe Thik Talk Write berada pada kriteria baik dengan rata-rata 79,81. Hal ini disebabkan siswa mulai terbiasa menggunakan kemampuan komunikasi matematika dalam menjawab soal.

3. Terdapat pengaruh yang signifikan penerapan model pembelajaran kooperatif tipe Thik Talk Write terhadap kemampuan pemecahan masalah dengan hasil uji hipotesis peningkatan kemampuan pemecahan masalah diperoleh nilai sig. ( 2 tailed) $0,000<$ 0,05 menunjukkan bahwa hipotesis h1 diterima.

4. Terdapat pengaruh yang signifikan penerapan model pembelajaran kooperatif tipe Thik Talk Write terhadap kemampuan komunikasi matematika dengan hasil uji hipotesis peningkatan kemampuan komunikasi matematika siswa diperoleh nilai sig. ( 2 tailed) $0,015<0,05$ menunjukkan bahwa hipotesis $\mathrm{h} 1$ diterima.

\section{DAFTAR PUSTAKA}

Ansari, B. I. (2012). Komunikasi Matematik dan Politik. Banda Aceh: Yasayan Pena.

Arends, R. I. (2008). Learning to Teach. New York: Mc Graw Hill.

BSNP. (2006). Standar Isi, Standar Kompetensi dan Kompetensi Dasar SMK/MAK. Jakarta: Badan Standar Nasional Pendidikan. 
Hamdayana, J. (2014). Model dan Metode Pembelajaran Kreatif dan Berkarakter. Bogor: Ghalia Indonesia.

Hodiyanto. (2017). Komunikasi Matematika Dalam Pembelajaran Matematika. AdMathEdu, $7(01), 9-18$.

Huda, M. (2013). Model-model Pengajaran dan Pembelajaran. Yogyakarta: Pustaka Pelajar.

Husna, A. (2016). Pengaruh Penerapan Strategi Pembelajaran Think Talk Write Terhadap Kemampuan Komunikasi Matematika Siswa Kelas VIII SMP Negeri Kecamatan Lembah Gumanti. Jurnal Pythagoras, 5(April), 6-11.

Ilyas, M. (2015). Metodologi Penelitian Pendidikan Matematika. Bandung: Pustaka Ramadan.

Komalasari, K. (2010). Pembelajaran Kontekstual, Konsep dan Aplikasi. Bandung: PT Refika Aditama.

NTCM. (2004). Overview: Standards for School Mathematics. Problem Solving. Reston VA: National Council of Teachers of Mathematics.

Soimin, A. (2016). 68 Model Pembelajaran Dalam Kurikulum 2013. Yogyakarta: Ar-Ruzz Media.

Sugiyono. (2018). Metode Penelitian Kuantitatif. Bandung: Alfabeta.

Suherman, E. (2003). Strategi Pembelajaran Matematika Kontemporer. Bandung: UPI.

Suyatno. (2009). Menjelajah Pembelajaran Inovatif. Sidoarjo: Masmedia Buana Pustaka.

Yuniarti, Y. (2016). Pengembangan Kemampuan Komunikasi Matematika dalam Pembelajaran Matematika di Sekolah Dasar. EduHumaniora |Jurnal Pendidikan Dasar Kampus Cibiru, 6(2), 109-114. https://doi.org/10.17509/eh.v6i2.4575 